\title{
Performance of the Higher Education Students Loans Board in Human Capital Investment from 2005-2015
}

\author{
Albert Zephaniah Memba ${ }^{1} \&$ Zhao Zun Feng ${ }^{2}$ \\ ${ }^{1}$ Department of Educational Economics and Management, Faculty of Education, Northeast Normal University, \\ Changchun, Jilin, China \\ ${ }^{2}$ School of Foreign Languages, Northeast Normal University, Changchun, Jilin, China \\ Correspondence: Albert Zephaniah Memba, Department of Educational Economics and Management, Faculty of \\ Education, Northeast Normal University, No. 5268, Renmin Street, Changchun, Jilin Province, 130024, China. \\ Tel: 86-186-8664-0477.E-mail: a_memba@hotmail.com
}

Received: May 4, 2016

doi:10.5539/hes.v6n3p48
Accepted: May 27, 2016

Online Published: July xx, 2016

\begin{abstract}
Many studies conducted on the Higher Education Students Loans Board (HESLB) have mostly concentrated on its success, sustainability and effectiveness on loans issuance and repayment. None had focused on its performance towards human capital investment. This study sought to explain and analyze HESLB's performance in human capital investment, which in this study has been operationalized as financing of higher education.

The study retraced the development of Higher education financing from early days of independence in Tanzania to the inception and operationalization of the HESLB. Data were collected, analyzed and interpreted with view to answering research questions on the performance of the HESLB.

It was concluded that despite the increasing budgeting trend in favour of the loans board, its ability to sustain itself through education loan repayment was still minimal, which can be interpreted as HESLB's little contribution to human capital investment. It was suggested the financing strategy of higher education in Tanzania for sustainable human capital investment be re-analyzed to ensure economic growth and development of the country.
\end{abstract}

Keywords: human capital investment, financing, higher education, higher educations students' loans board, cost sharing

\section{Introduction}

\subsection{Background to the Problem}

The Higher Education Students Loans Board (HESLB) tugs along a long history of the United Republic of Tanzania government's attempts and efforts to finance higher education. It is important to note that the board started as an idea for cost sharing, shifting some of or all the burden of financing higher education to other stakeholders, other than the government.

The HESLB Lending Manual (2007) defines cost sharing as the shift of the at least part or all of higher education costs from government to beneficiaries including parents, students and communities. Elsewhere, Bruce Johnstone (2004) defines cost sharing as a "worldwide phenomenon in which the burden of costs of higher education is shifted from exclusive or near exclusive of independence of the government/or tax payer to some reliance on the parents and or students to cover the living costs of students". Ishengoma (2004) also defines cost sharing as the process of shifting of the burden for financing higher education away from the state and into student's families.

Various scholars have suggested Tanzania has passed through six distinct stages of higher education financing. Notably, these stages are:

\subsubsection{Colonial Era to Independence (1950s-1964)}

Cost sharing dates back to 1954 when the Colonial government issued bursaries to poor students. At this time, tuition fees in higher education applied to all students regardless of their socio-economic class or race and the colonial government provided bursaries to students who would not afford higher education (Chatama, 2014). The 
responsibility of determining students who were in need of bursaries was entrusted to local authorities. The bursaries reached the intended students through the local government and were recovered in full from post-graduation salaries, an exercise conducted by the local authorities (Ishengoma, 2004).

\subsubsection{The National Service Scheme (1964-1974)}

In the few years that followed the independence, the government abolished the colonial cost sharing system and introduced the National Service Scheme. This implied Cost Sharing Sensu Scritu had ceased to exist insteadly the students were supposed to "build the nation", as Chatama (2004) aptly puts it. This practice demanded all graduates of Higher Learning Institutions (HEIs) to spend six months in the national service. Upon completion of their stint in the National Service, they were guaranteed employment in the public sector where they continued receiving only $40 \%$ of their salary for 18 months. According to Ishengoma (2004) the remaining $60 \%$ of the salary was intended to cover for government's bursary on the graduates during their studies.

\subsubsection{The Musoma Resolution}

At this stage the government opted to abolish the previous bursary system and chose to bear all costs of higher education. Consequently, the National Service term was extended from six to 12 months where all HEIs entrants were required to serve the government for two years before joining the institutions. On the other hand, the government started paying tuition fees, student travel costs, off pocket allowances, student union contributions, caution money as well as other higher education allowances. It is also at this stage that students started signing bonds to work with government for "at least five years on graduation" (Ishengoma, 2004).

\subsubsection{Cost Sharing Policy 1988-1994 (PHASE 1)}

The government's ability to finance higher education was highly affected by the global financial crisis of 1970s and 80s, which was followed suit by the war with Uganda of 1978-1979. These two development had negative impact on government's ability to finance higher education. As a result, the government was compelled to alter its policy on financing higher education. This period coincided with the government's decision to bow to the pressure of the International Monetary Fund (IMF) and World Bank conditions as a precursor to the advent of the Structural Adjustment Programs (SAPs).

In 1988, the government endorsed the cost sharing policy as a way of improving her shrinking budget (NHEP, 1999). The formal announcement of the Cost sharing policy was made public in 1992 but its implementation began in the academic year 1992/1993 where students were required to pay for transport, caution money, registration fees, application fees, student union and entry examination fees from their own sources (MSTHE, 2004).

\subsubsection{Cost Sharing Policy from 1994-2004 (PHASE 2)}

This phase became operational in the academic year 1994/1995. Unique in this phase was the requirement for students to bear their own food, accommodation and out of pocket costs on top of what they had started to pay in the Phase 1 of the policy implementation. This caused development of huge inequalities among the beneficiaries of the policy. The government acknowledged the fact that not all students would afford the said costs hence the introduction of the Students' Loan Scheme (Chatama, 2014; MSTHE, 2004). It was anticipated this way the eligible and needy students could borrow money from the government the required amount.

\subsubsection{Cost Sharing Policy from 2004 to Date (PHASE 3)}

The third phase of Cost Sharing was largely characterized by the establishment of the Higher Education Student's Loans Board (HESLB). The Board was established under the Act of Parliament number 9 of 2004, which has since then been amended by the Act of Parliament number 9 of 2007 CAP 178. Officially, HESLB began its operations in July 2005 (HESLB, 2011).

The act, among other things, empowers the Board to administer loans to eligible and needy Tanzanian students as well as collect repayment for all loans issued to beneficiaries since 1994 so as to make the scheme sustainable (Ibid.)

\subsection{Statement of the Problem}

When Cabinet endorsed the Cost Sharing Policy in 1988, which was followed by its formal announcement in 1992, students enrolled in higher education institutions were required to pay for their own transport costs, caution money, registration, application, students union and entry examination fees (Chatama, 2014). However, due to income inequalities and poverty as well as change-resistant mindset (which was contrasting liberal market economy thinking, which the government had just implemented), parents and guardians were not ready to participate in cost sharing. 
Therefore, the government institutionalized the Higher Education Student's Loan Scheme (HESLS) in 1994 to assist the needy students and encourage cost sharing in higher education (Ishengoma, 2004; Galabawa, 1991; Ally, 2015). Since its introduction, the scheme was able to provide loans beginning with $1.7 \mathrm{bn} /$ - in 1994/95 to 9.9bn/-in 2004/05 (HESLB, 2009).

One of the biggest challenges to befall the scheme was its ineffectiveness in recovery of the loans in over 10 years (from its inception in 1994) of its operation. This called for strict analysis of the scheme's legal framework with view to protecting it more from revenue loss. Another anomaly was the schemes resilience on funding students enrolled on public schools only. Criticism was leveled on the fund for this anomaly because it was being funded by the government from taxes and other statutory payments. Coupled with other explanations, such as the growing underfunding of the Higher Education (HE) sector and the mushrooming of the private higher education institutions (Public Expenditure Review, 1994/95-2004/05), the government opted to introduce the Higher Education Students Loans Board in 2005. The Board was established by the Act of Parliament No. 9 of 2004 which has also been amended by Act No. 9 of 2007 CAP 178 (HESLB, 2008-2011) with the major aim of properly managing the students loan scheme, which was started in 1994 (NHEP, 1999).

Despite the remarkable successes that the Board has recorded since 2005, as a result of reforms on the Higher Educations Students Loans Scheme (HESLS), such as the increase of higher education institutions, increase of budgetary allocation for the Higher Education sector, growth of enrolment and increase of funds allocated for students loans (Ishengoma, 2007; Chatama, 2014; Ally, 2015; Nyahende, 2013; Makulilo, 2014) there has been a decrease in the percentage share of higher education in the total education sector budget. But the biggest drawback facing HESLB is that it is still heavily dependent on government subvention.

Education can be thought of as an investment in human capital, which is similar to investment in physical capital. Individuals, in this case, decide to invest in their own education, at a margin just as a firm decides to invest in a new machinery. The investment entails current costs but yields future benefits. In Tanzania, investment in higher education is highly regarded because of its vitality in economic development. To ensure sufficient investment in higher education, HESLB has been given the power to act as a financier for investments in higher education.

Although hailed as a success by some researchers (Ally, 2015; Nyahende, 2013a, 2013b; Makulilo, 2012), the decrease in the percentage share of the budget poses a threat to the ability of the fund to sustainably finance students for higher education, which is vital measure in the development of human capital. Coupled with dwindling percentage share of education budget, loan recovery pace has not been matched with that of issuing. The Fund lags far behind the break-even point. This discord further sharpens its inability to finance human capital investment sustainably especially when a look is casted on the enrolment in higher education. Enrolment into higher education is still quite low. In a country of over 40 million people, the gross enrolment ratio remains around 1\% (World Bank, 2010; Nomura, 2011). Whilst the expansion of private higher education enrolment has had a significant impact in boosting access, these universities are relatively small when compared to the public ones.The gist of the study is, therefore, to critically examine, and analyze, the performance of the HESLB in human capital investment.

\subsection{Significance of the Study}

This study is significant to the discipline of Educational Economics and Management of higher education because it examined, critically, the performance of HESLB in human capital investment. Unlike other areas, the performance of HESLB in human capital investment has not received sufficient academic attention. This is study is an attempt towards bridging that gap. By critically studying the performance of the HESLB in human capital investment, the study paints a clearer picture of the role of higher education in Tanzania towards economic development. It also serves as a launch pad for advice to policy makers regarding sustainable human capital investment. The study identifies the pros and cons of the HESLB performance towards human capital investment. In so doing, the study has also opened a new avenue of research in the discipline of Educational Economics and Management. Further studies in the area can now be pursued.

\subsection{Research Objectives}

The key objective of this study is to explain the performance of theTanzania's Higher Education Students Loan Board (HESLB) in Human Capital investment from 2005 and 2015. The study sought to realize the following specific objectives:

1) To explain the functioning of the HESLB in Human Capital Investment from 2005 to 2015.

2) To analyze the financial sustainability of HESLB in Human Capital Investment from 2005 to 2015.

3) To evaluate HESLB loan recovery trends from 2005 to 2015. 


\subsection{Research Questions}

An overall research question "What is the performance of the Higher Education Students Loan Board (HESLB) in human capital investment through financing higher education?" guided this study. However, the following questions were posed to further clarify the main. These included:

1) How did the HESLB function in human capital investment through higher education financing from 2005 to 2015 ?

2) What is the financial status of the HESLB?

3) What loan recovery efforts did HESLB use?

\subsection{Literature Review}

In most countries, higher education has become a large, complex enterprise. Perhaps most important is the fact that postsecondary education is recognized as a central element in modern society (Altibach, 2007). This view is seconded by Schultz (1981) who observes the acquired abilities of people-their education, experience, skills and health-are basic in achieving economic progress. This is to say, university education and economic development are inextricably linked (Makulilo, 2012). Academic institutions employ thousands of people and educate tens of thousands - or in some cases hundreds of thousands. Higher education has become big business. In other words, this implies university education has become a huge economic activity.

\subsubsection{The Development of Higher Education in Tanzania}

Higher Education is a recent phenomenon in Tanzania. Up until 1999, 31 years after the independence of Tanganyika from Britain, Tanzania did not have a common conceptualization and a working definition of what constituted higher education. This pointed not only to pitfalls and gaps in the national philosophy guiding the provision and processes of higher education but also to potential operational problems, conflicts and or dissonance with respect to allocation of resources, governance, delivery systems, curricular provisions and the final products of the processes. Tanzania's higher education system has grown from a relatively simple to a complex one. The system has grown from only one institution of higher education (a university college) in 1961 to more than 140 tertiary training insitutions in 1999 (URT, 1999).

University education refers to education given in universities to equip individuals with the necessary mental and intellectual skills to develop them into useful members of the community (Kyllonen, 2012). According to Kyllonen (2012), university education is valuable for the individual and also beneficial to the development of the economy and the society in general.

On the other hand, University education simply refers to education offered by an institution of Higher education and research. Such institution offers both undergraduate and postgraduate degrees in various fields. Higher education is the top of the education pyramid and determines to a large extent the state of education system of a country, especially its quality (Sanyal, 2005).

As we have noted, Higher education is education beyond the secondary level, featuring mostly education at the college or university level. Institutions of higher education include not only colleges and universities but also professional schools in a particular field for example education, laws, medicine, business, engineering, etc. At the end of the prescribed course of study a degree, diploma or certificate is awarded. However, the National Higher Education Policy (1999) defines higher education as:

"The scope of knowledge and skills imparted within the tertiary level of education. This excludes Primary and Secondary education".

Furthermore, the policy adds: "there are two clearly distinct levels of training institutions in higher education provision, namely, academic full professional training and intermediary professional education and training institutions. These are represented by university and non-university professional training institutions". Each has a clearly delineated mission, objectives and curricular orientation and concentration. Universities are expected to concentrate on Research, Teaching and Public Service or Consultancy. Intermediate institutions of higher education are devoted to Human Resource development through pedagogical mission of teaching, instructing, and career training and role-modeling. 


\section{Method}

This study was informed by the Human Capital Theory, which assumes that individuals and societies invest in higher education for assumption of yielding better benefits in the future (Al-hajry, 2002). The study focused on the Higher Education Students' Loans Board (HESLB) function of financing Higher education in Tanzania. In this study we have operationalized financing higher education as investment in human capital.

The study is a qualitative research which has been defined extensively (Flick, 2009; Yin, 2011; Stake, 2010; Savin-Baden et al., 2010; Maxwell, 2013; Sharan, 2002; Wiersma \& Jurs, 2009). The scholars advocate for the effectiveness of qualitative research in this type of study as largely lying on its flexibility. In order to realize its objective, the study employed a historical research design, which Wiersma and Jurs (2009) define as "systematic profess of searching for the facts and then using the information to describe, analyze and interpret the past".

The study employed the Document Analysis technique as a qualitative research method (Bowen, 2009). Document Analysis technique has been defined as a systematic procedure for reviewing or re-evaluating documents - both printed and electronic computer-based and internet transmitted materials (Ibid.). Similar to other analytical methods in qualitative research, Document Analysis requires that data be examined and interpreted in order to elicit meaning, gain understanding, and develop empirical knowledge (Corbin \& Strauss, 2008; Rapley, 2007).

\subsection{Sampling Design}

The study employed a purposive sampling design which means that they "purposefully choose that (which) fits the parameters of the project's research questions, goals and purpose" (Tracey, 2013). As explained by Wiersma and Jurs (2009) Purposeful samples are very different from random samples, not only in how they are selected but also in the logic of their use. The logic of purposeful sampling is based on a sample of information rich cases that is studied in depth.

\subsection{Sampling Unit}

The sample covered institutions related with the higher education in Tanzania. These included the Ministry of Education and Vocational Training (MoEVT), the Higher Education Students Loans Board (HESLB), the Tanzania Commission for Universities (TCU) and National Bureau of Statistics (NBS).

\subsection{Sampling Procedures}

In the purposive sampling design, selection of participants is also purposive. Therefore, four institutions were purposeful selected as participants. These included the MoEVT, HESLB, TCU and NBS. While the budgets of the MoEVT for the 10 year period (i.e., 2004/05-2014/15) were sampled, the HESLB budgets and Repayment trends in the said time frame were also included in the sample. Data on enrolment and accreditation of higher education institutions were also collected during the time, while various statistics from the NBS was sampled for purposeful clarification of concepts and trends. The MoEVT budgets, from 2004/05 to 2014/15, were collected from the Ministry's archives. Where there were gaps, online resources were consulted. The HESLB budgets for the same time frame were provided after approval of the request.

\subsubsection{Sample and Sample Size}

The sample, for the purpose of the study, included all budget reports of the Ministry of Education and Vocational Training and Higher Education Students Loans Board from 2005 to 2015; HESLB loan repayment trend reports, HESLB strategic plan, Higher education enrolment trends reports and Facts and Figures from the Tanzania Commission for Universities as well as Economic trends reports from the NBS.

\section{Results and Discussion}

\subsection{The Ministry of Education and Vocational Training (MoEVT)}

By looking at the budget of the Ministry of Education and Vocational Training (MoEVT), the section highlights the direction which the budget is taking. The logic of looking at the budget lies in the fact that as most of the HESLB finances seem to come from the MoEVT budget. Flactuations in the MoEVT budget may have similar effects on the HESLB finances hence impact negatively on its performance towards human capital investment.

The findings, as depicted in Table 1 have shown that the Budget of the Ministry of Education and Vocational Training (MoEVT) continued to improve along the years, reporting an increase from 4.2\% in 2005/06 to 23.1\% in $2012 / 13$, which is the highest in the period, before slightly dipping to $12.3 \%$ in $2014 / 15$. However, its presentation did not help much in the analysis of its first five years, i.e., 2005/06-2010/11 because of the format of the budget. 
Table 1. MoEVT budget showing distribution among sectors (2005/2006-2014/2015) in Tshs. Billion $(000,000,000)$

\begin{tabular}{lllllll}
\hline S/no. & Year & General & Development & Others & Total & $\%$ \\
\hline 1 & $2005 / 2006$ & 111.1 & 29.9 & 139.60 & 280.6 & 4.2 \\
2 & $2006 / 2007$ & 133.9 & 105.7 & - & 239.6 & 3.6 \\
3 & $2007 / 2008$ & 240.0 & 47.3 & - & 287.3 & 4.3 \\
4 & $2008 / 2009$ & 397.9 & 129.6 & - & 527.5 & 7.9 \\
5 & $2009 / 2010$ & 377.9 & 129.8 & 139.60 & 647.3 & 9.7 \\
6 & $2010 / 2011$ & 72.0 & 453.9 & 452.00 & 977.9 & 14.6 \\
7 & $2011 / 2012$ & 71.8 & 135.5 & 92.80 & 300.1 & 4.5 \\
8 & $2012 / 2013$ & 936.4 & 535.5 & 72.60 & $1,544.5$ & 23.1 \\
9 & $2013 / 2014$ & 98.7 & 518.1 & 454.80 & $1,071.6$ & 16.0 \\
10 & $2014 / 2015$ & 93.3 & 250.9 & 478.70 & 822.9 & 12.3 \\
& Total & $\mathbf{2 , 5 3 3 . 0}$ & $\mathbf{2 , 3 3 6 . 2}$ & $\mathbf{1 , 8 3 0 . 1}$ & $\mathbf{6 , 6 9 9 . 3}$ & $\mathbf{1 0 0 . 0}$
\end{tabular}

Source: MoEVT budget Speech Books (2004/2005-2014/2015).

Usually, the MoEVT budget that is presented to the parliament is split into three thematic areas namely, the General (Recurrent Budget), Development and Others. It was observed that the first five years went without the "Others" budget category. It can be suggested that the presentation format reflected the nature of the education sector at that time, where it was being governed by two ministries, the Ministry of Education and Culture (MoEC) and the Ministry of Science Technology and Higher Education (MSTHE). In the later years, it can be observed the budget is distributed among the three categories.

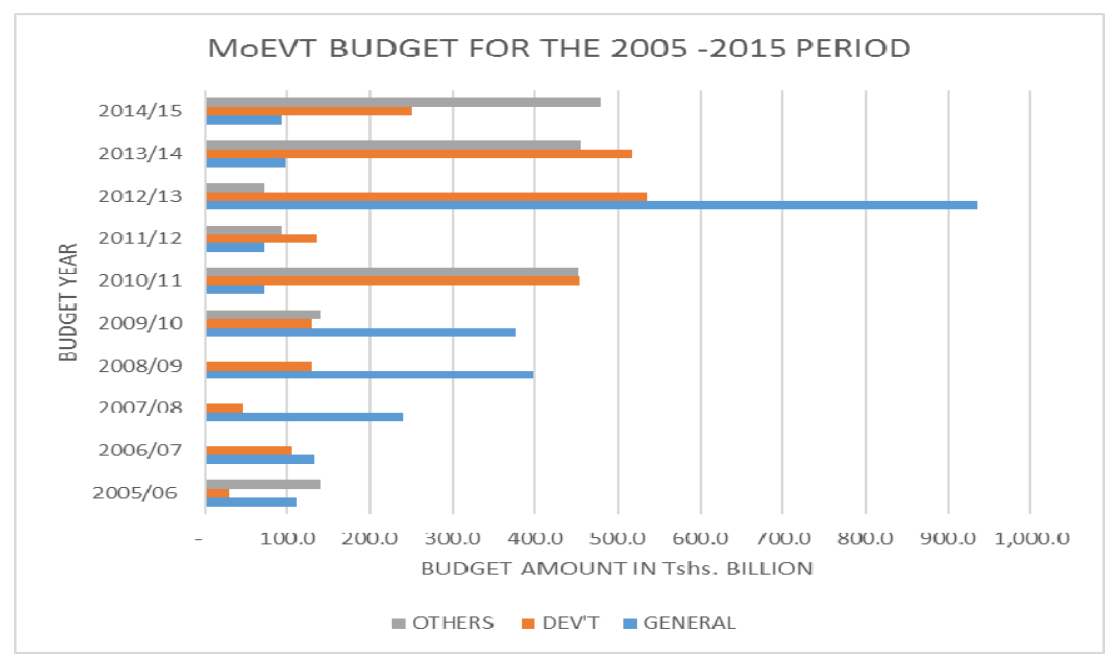

Figure 1. The MoEVT budget for 2005/2006-2014/2015 in Tshs. Billion

The Findings also indicated a sharp rise in the budget for the General (Recurrent) sector, which stood at Tshs. Billion 900 in 2012/2013. This can be explained by the government's desire to clear a backlog of recurrent expenses, including professors and academic staff allowances, in bid to rekindle motivation among the academics towards their role in economic development. 


\section{MOEVT BUDGET BY SECTORS (TOTALS IN Tshs. BILLION)}

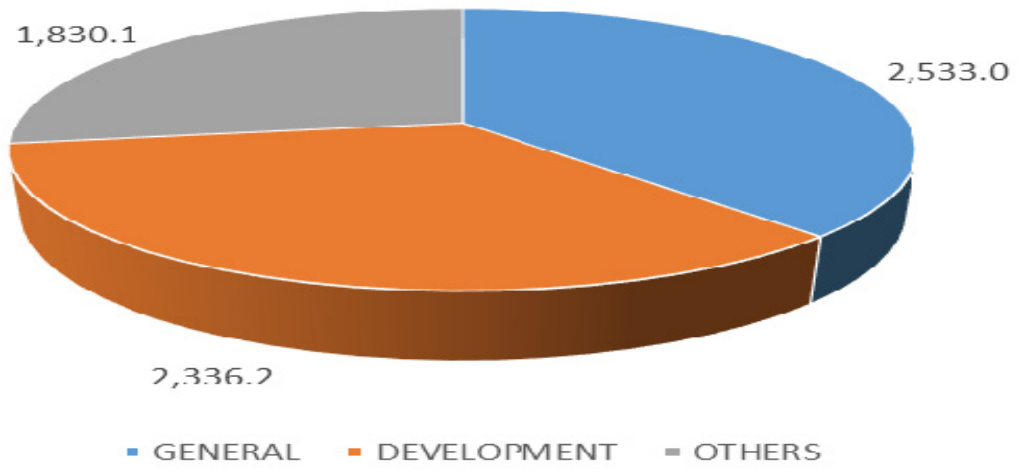

Figure 2. The MoEVT budget by thematic sectors

However, in real terms, it was the development budget that saw massive growth in the 2005/2006-2015/2016 decade, although there were episodic rises in the General (Recurrent budget) category. The "Others" category remained almost unchanged throughout the period under observation, with the lowest of the budget allocation as Figure 2 aptly explains this.

The observed increases in the budget implied a huge improvement in the higher education budget. The findings have shown a $38.0 \%$ of the entire budget was dedicated for development. It can be suggested the budget was that big owing to construction of new and renovation of higher learning institutions with view to increasing access and participation in the higher education. It is around this time that major public universities in Tanzania received funds for renovation. The University of Dodoma (UDOM) started operating at full capacity around this time, while there were expansion of facilities at the University of Dar es Salaam (UDSM), Sokoine University of Agriculture (SUA) and the Open University of Tanzania (OUT).

\subsection{The Higher Education Students Loans Board (HESLB)}

This section critically looks at the HESLB budget from its inception in 2005/06 to 2014/15. Understanding the budgeting process in the higher education paves way to the general understanding of the performance of higher education in human capital investment. The decade under observation is crucial in the understanding of higher education financing in Tanzania. It marks a slight departure from direct government financing of higher education. At this stage, HESLB is introduced as the key financier of higher education.

The findings in Table 2 depict the budget of the Higher Education Students Loans Board (HESLB) since its inception. The table shows the HESLB budget increasing significantly in the decade under study although there still existed a sizeable differences between the planned budget and the actual budget. But, it is worth noting that totally, HESLB actual budget suffers a Tshs. 105 Billion deficit in the 10 year period.

Table 2. HESLB budget in Tshs Billion (2005/2006-2014/2015)

\begin{tabular}{lllll}
\hline S/No & FIN/YEAR & PLANNED & ACTUAL & $\%$ \\
\hline 1 & $2005 / 06$ & 56.1 & 56.1 & 100.00 \\
2 & $2006 / 07$ & 76 & 92 & 121.05 \\
3 & $2007 / 08$ & 110.7 & 101.2 & 91.42 \\
4 & $2008 / 09$ & 140.2 & 145.9 & 104.07 \\
5 & $2009 / 10$ & 204 & 197.4 & 96.76 \\
6 & $2010 / 11$ & 252.9 & 237.8 & 94.03 \\
7 & $2011 / 12$ & 386.4 & 317.8 & 82.25 \\
8 & $2012 / 13$ & 345 & 318.1 & 92.20 \\
\hline
\end{tabular}




\begin{tabular}{lllll}
\hline 9 & $2013 / 14$ & 325 & 328.3 & 101.02 \\
10 & $2014 / 15$ & 341.1 & 337.8 & 99.03 \\
& & $\mathbf{2 2 3 7 . 4}$ & $\mathbf{2 1 3 2 . 4}$ & $\mathbf{9 5 . 3 1}$ \\
\hline
\end{tabular}

Source: HESLB, 2015.

The government's failure to meet HESLB budget renders the board incapable of playing its key role in human capital investment. On the other hand, it provides a leeway for HESLB to find an excuse for failure to reach its objectives. While it is not very noticeable in the early years of HESLB budgeting, the findings have shown existence of a big gap between the planned and the actual budgets, especially between years 2010/2011-2012/2013.

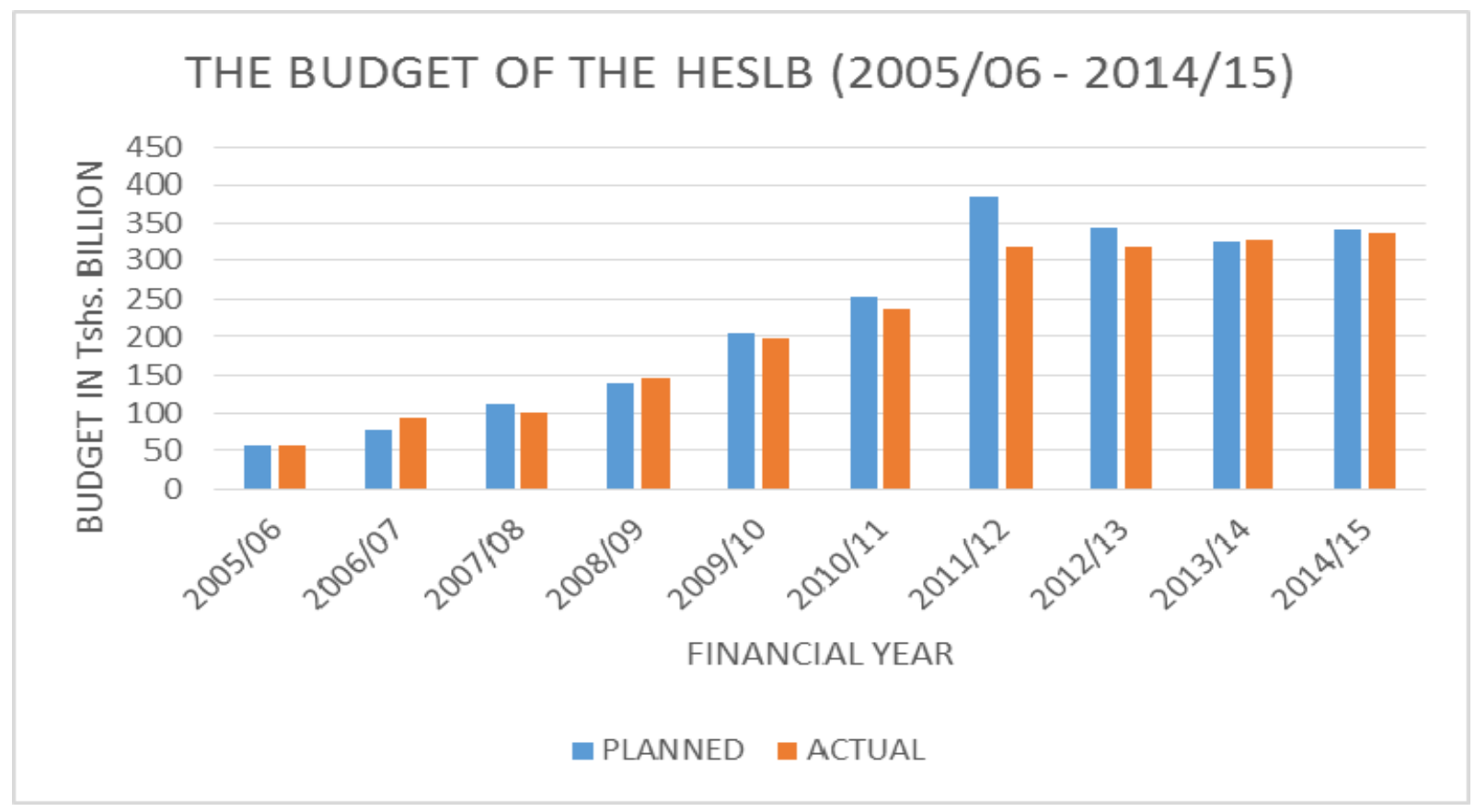

Figure 3. HESLB showing planned vs Actual (2005/2006-2014/2015)

Figure 3 further clarifies the gap in its analysis of the HESLB Budget. With the insertion of the deficit column in the budgets, the findings showed the board has been operating below expectations. In turn, the findings paint one picture the board has not diversified its sources of funding, except the one and only government subvention. The findings further show that throughout the 10-year period under study, the loans board operated well below its capacity. One explanation could be given is that the board had been largely underfunded by the government throughout the observed period. 


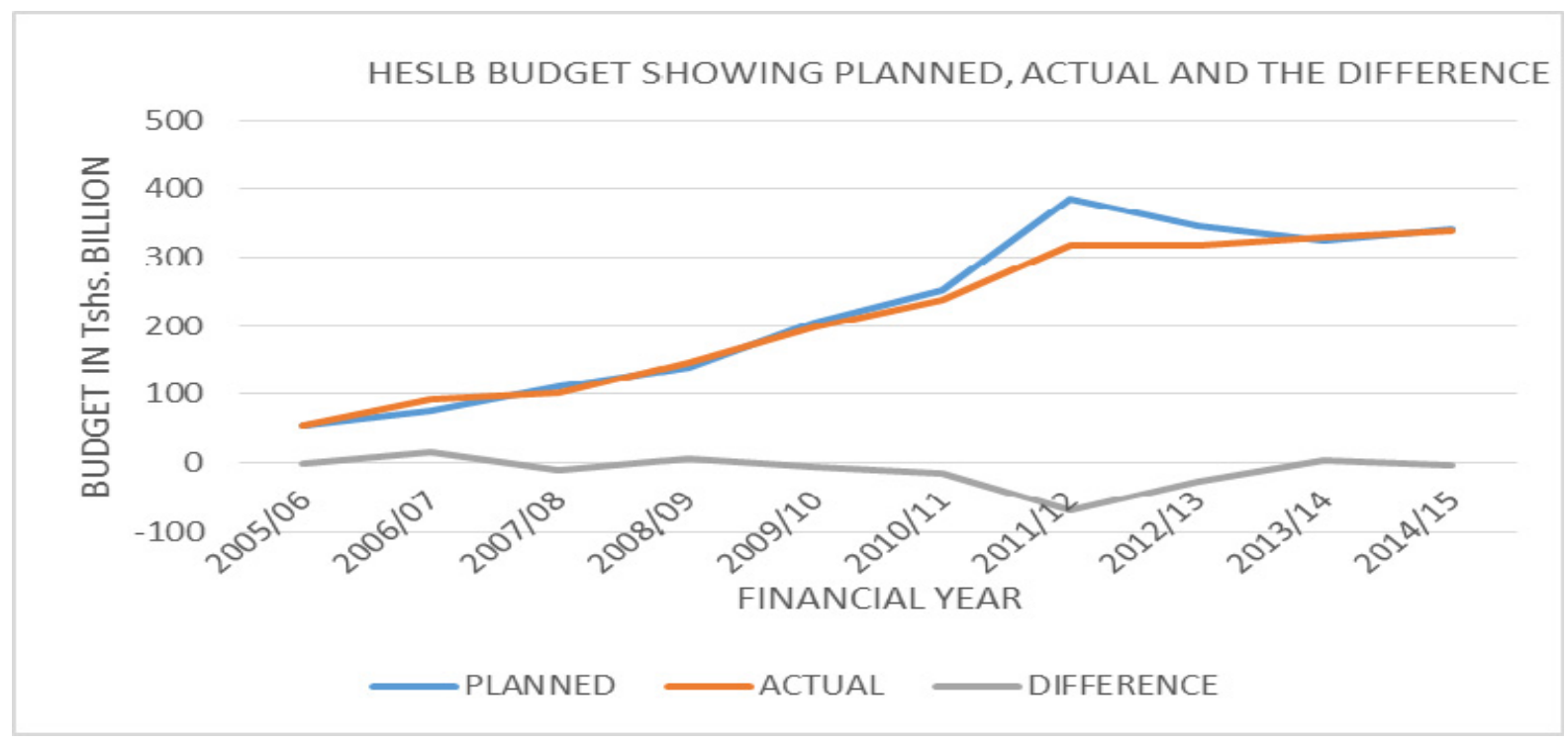

Figure 4. HESLB budget showing planned, actual vs deficit (difference)

\subsection{Trends in Higher Education Students Loans Repayment}

Unlike in the other phases of cost sharing in which Tanzania passed through, the HESLB was designed to be sustainable. This was to be realized from the collection of repaid loans. The recollected loans are supposed to create a revolving fund from which other applicants could access their loans. This part looks, therefore, at the progress of loan repayment against the loan issuance. The intention here is to analyze the sustainability of fund in financing higher education in Tanzania.

The findings painted a very gloomy picture regarding the trends in loan repayment to the HESLB. Such developments forecasted a huge doubt on the HESLB sustainability based on the above suggestions. The findings in the Table 3 and Figures 5 and 6 show that the board had a 90 Tshs Billion deficit from its planned collections.

Table 3. Loan repayment trends in Tshs. Billion (2006-2016)

\begin{tabular}{lllll}
\hline S/No & Financial Year & PLANNED & ACTUAL & DIFFERENCE \\
\hline 1 & $2006 / 07$ & 0.0 & 0.05 & 0.05 \\
2 & $2007 / 08$ & 3.4 & 0.86 & -2.54 \\
3 & $2008 / 09$ & 5.1 & 1.18 & -3.92 \\
4 & $2009 / 10$ & 5.1 & 2.15 & -2.95 \\
5 & $2010 / 11$ & 7.2 & 4.41 & -2.79 \\
6 & $2011 / 12$ & 12.2 & 11.51 & -0.69 \\
7 & $2012 / 13$ & 17.9 & 14.85 & -3.03 \\
8 & $2013 / 14$ & 28.7 & 18.09 & -10.66 \\
9 & $2014 / 15$ & 35.0 & 21.67 & -13.33 \\
10 & $2015 / 16$ & 50.2 & & -50.24 \\
& TOTAL & $\mathbf{1 6 4 . 9}$ & $\mathbf{7 4 . 7 6}$ & $\mathbf{- 9 0 . 1 0}$ \\
\hline
\end{tabular}

Source: HESLB (2015). 
Other researchers claimed this phenomenon was due to legal and operational limitations that the board was founded upon (Chatama, 2014). For example, the legal framework upon which the borrowing was built allowed borrowers 10 years of flexibility and room to manouvre out of the loan repayment.

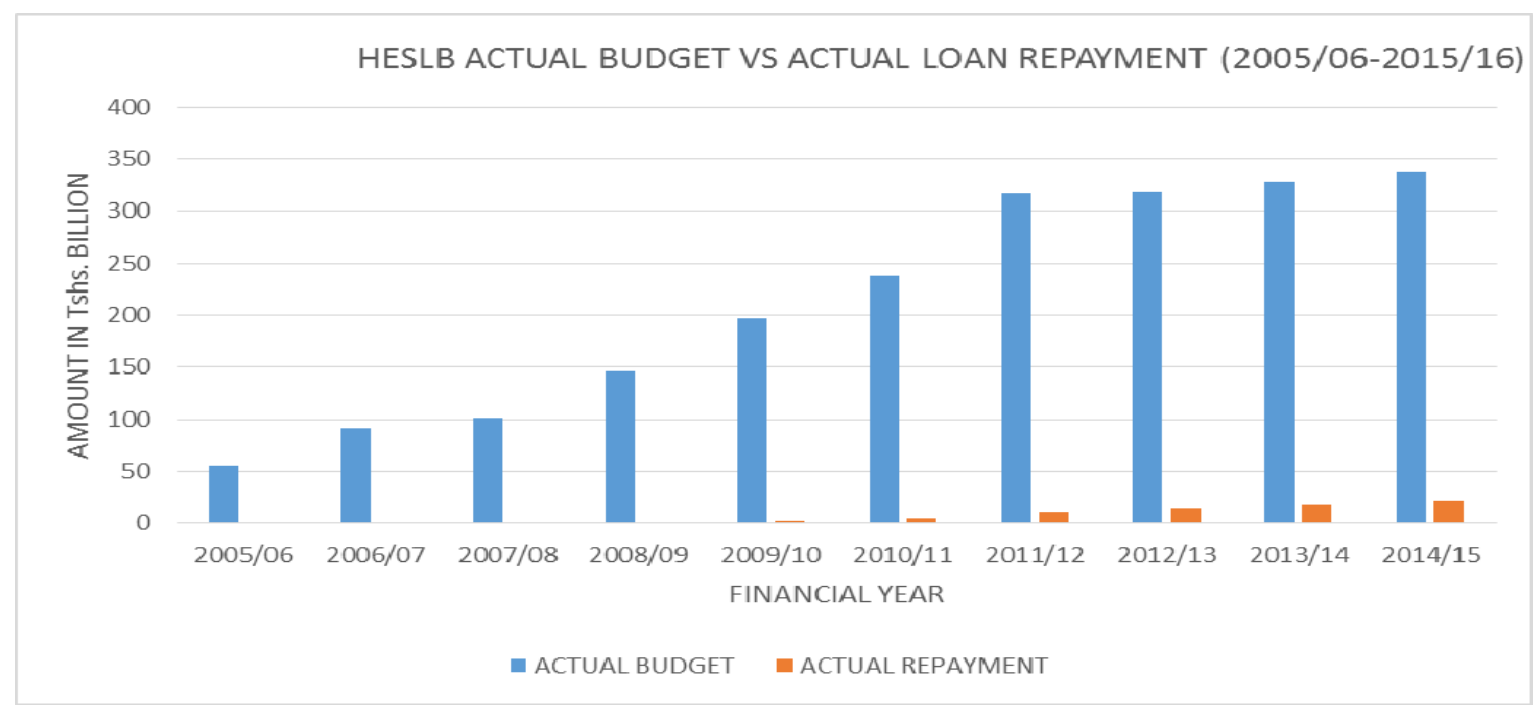

Figure 5. HESLB budget showing actual budget vs actual repayment in Tshs. Billion

Figure 6 sums up the findings on the difficulty of bridging the deficit between the expected repayment amounts and amount collected from graduates (planned and the actual budgets). The deficit seems to funnel out and plunge down below the - 50 Tshs. Billion mark. It can be further suggested the deficit line has been getting bigger with time almost inversely proportional as the actual budget. This implies that the task of bridging the deficit is almost unrealizable as the gap continues to widen. The probable solution would be to think of another alternative of collecting the repayment as the current, voluntary loan repayment system does not seem to be effective.

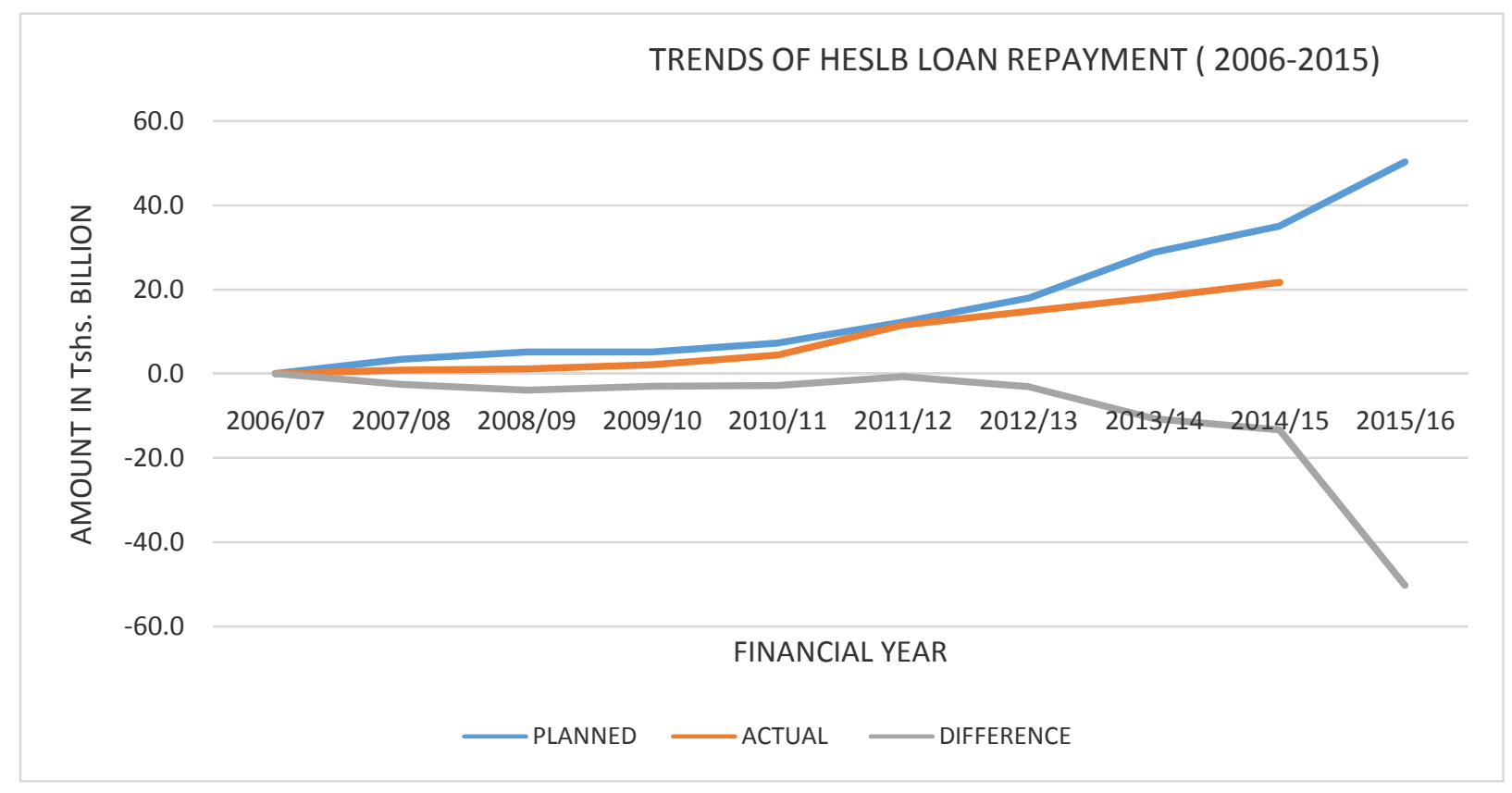

Figure 6. Trends of HESLB loan repayment in Tshs. Billion (2006-2015) 


\subsection{Comparison of the MoEVT vs HESLB Budgets}

The HESLB budget, which is a subset of the MoEVT budget, maintained a steady rise from 2005. The lack of flexibility on the growth of the budget may suggest planners in the government have not given human capital investement and the Board its deserved priority. When assessed against the backdrop of enrolment trends and proliferation of higher education institutions, the budget of the board, coupled with its inability to collect repayments does not guarantee sustainability of the fund. This observation as captured in Figure 7 augments the assumption that if it continues to operate the way it is, the HESLB will fail to meet the ever increasing and continuous rise in students financial requirements hence failing to sustain human capital investment in Tanzania, a vital ingredient for economic development of the country. Comparatively, the findings have shown the Budget of the Ministry of Education and Vocational Training (MoEVT), although on a rising trend from 2005/06, varied sparingly in the study period. The variations between years imply the shifting priority of the government in the education sector.

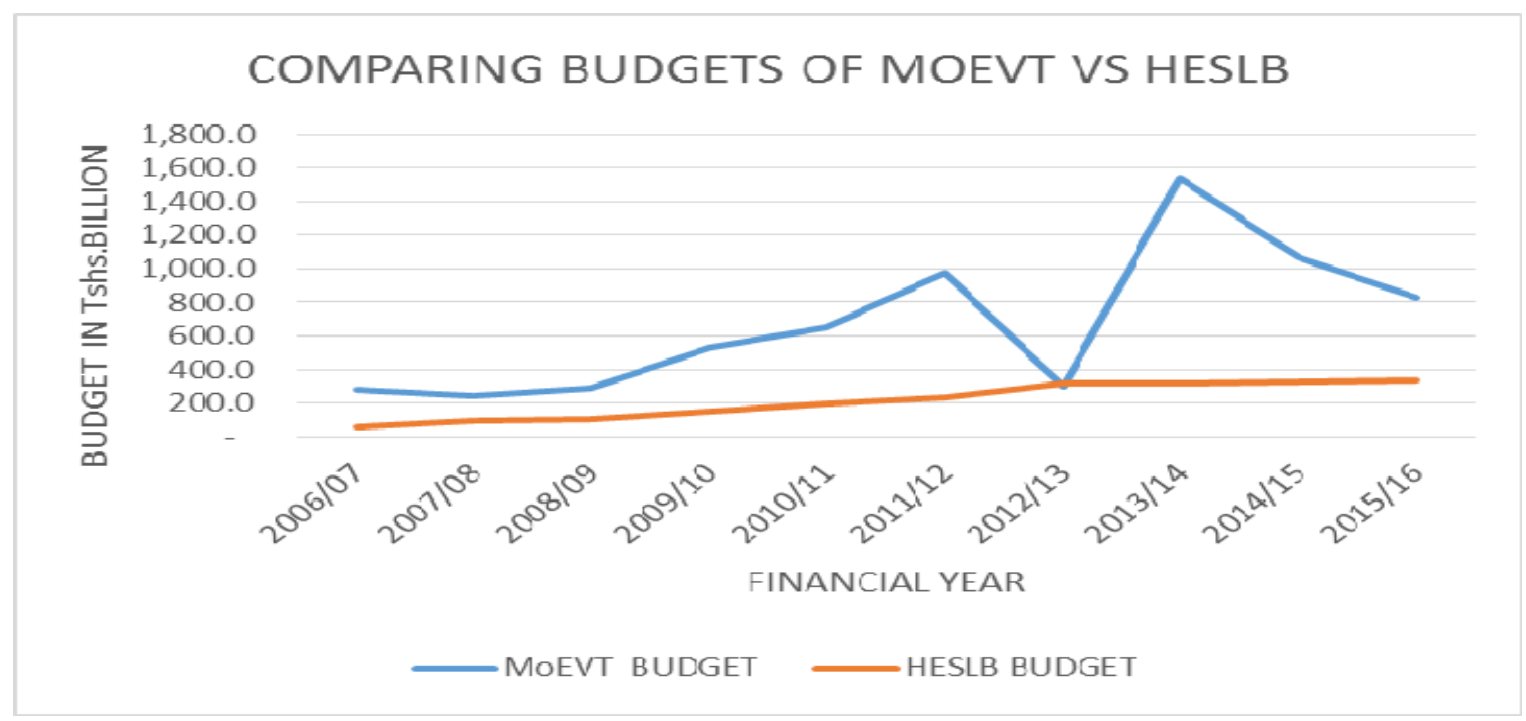

Figure 7. Comparing the MoEVT and HESLB budgets

\section{Conclusion}

This study, Performance of the Higher Education Students Loan Board (HESLB) in Human Capital Investment from 2005-2015, was aimed at critically assessing the performance of the board towards financing higher education, which was operationalized in the study to imply investment in human capital through provision of loans to students wishing to pursue higher education in Tanzania and abroad.

Results have shown the budget of the HESLB continued to increase although it also incurred huge deficits. This, on the one hand, could be interpreted as denting the funds noble mission of providing loans to the needy students wishing to pursue higher education in Tanzania and abroad, but also, its role in development of the country through creation of the much needed human capital.

The study further observed HESLB efforts to sustain its operations were not matched by the loan repayment pace. The loan repayment efforts fell too short of its own projections leaving the HESLB performance hanging in balance. As a result, this calls for the HESLB and stakeholders in the higher education sector to jointly re-think the financing strategy by avoiding over reliance on a single source - the government. Other effective mechanisms should be devised to ensure HESLB operates efficiently and sustainably. This can all be resolved by devising an effective financing model for higher education with the HESLB at its core. 


\section{References}

Al-hajry, A. S. (2002). Human Capital Theory and Financing of Higher Education in Oman (A Doctoral Thesis). Department of Economics, University of Sheffield, UK. Retrieved from http:/www.etheses.whiterose.ac.uk/3433/

Altbach, P. G., \& Knight, J. (2007). The internationalization of higher education: Motivations and realities. Journal of Studies in International Education, 11, 290. http://dx.doi.org/10.1177/1028315307303542

Bowen, G. A. (2009). Document Analysis as a Qualitative Research Method. Qualitative Research Journal, 9(2), 27-40. http://dx.doi.org/10.3316/QRJ0902027

Chatama, Y. J. (2014). Financing Higher Education: An evolution of cost sharing in Tanzania. Developing Countries Studies, 4(9).

Corbin, J. M., \& Strauss, A. L. (2008). Basics of qualitative research: Techniques and procedures for developing grounded theory. Los Angeles, CA. Sage Publications, Inc. http://dx.doi.org/10.4135/9781452230153

Flick, U. (2009). An Introduction to Qualitative Research (4th ed.).

Galabawa, J. C. (1991). Funding, Selected Issues and Trends in Tanzania Higher Education. Higher Education, 21, 49-61. http://dx.doi.org/10.1007/BF00132341

HESLB. (2009). Annual Reports and Financial Statements. Dar es Salaam.

HESLB. (2015). HESLB Strategic Plan. Dar es Salaam.

Ishengoma, J. M. (2004). Cost sharing and participation in Higher Education in sub-Saharan Africa: The case of Tanzania (PhD dissertation). State University of New York at Buffalo.

Ishengoma, J. M. (2010). Financing Public Higher Education Expansiion in sub Saharan Africa: Towards Ecclectic Business Models/Approaches. Investment in Higher Education: New Directions.

Ishengoma, J. M. (2010). Tanzania. In P. Pillay (Ed.), Higher Education Financing in East and Southern Africa. South Africa: Centre for Higher Education Transformation.

Johnstone, B. D. (2004). Higher Education accessibility and financial viability: The role of students loans. Paper in the Guni series on the social commitment of Universities in Higher Education in the World 2006, the Financing of Universities.

Johnstone, B. D. (2004a). The Economics and Politics of Cost sharing in Higher Education: Comparative Perspectives. Economics of Education Review, 20(4), $403-410$. http://dx.doi.org/10.1016/j.econedurev.2003.09.004

Johnstone, B. D. (2004b). Cost sharing and Equity in Higher Education: Implications of Income Contingent Loans. In P. Texteria, B. Jongbloed, D. Dill, \& A. Amaral (Eds.), Markets in Higher Education. Dordrecht, the Netherlands: Kluwer Academic Publishers. http://dx.doi.org/10.1007/1-4020-2835-0_3

Johnstone, B. D. (2004c). The Applicability of Income Contingent Loans in Developing and Transitional Countries. Journal of Educational Planning and Administration, 18(2), 159-174.

Luhanga, M. L., Mkude, D. J., Chijoriga, M. M., \& Ngirwa, C. A. (2003). Higher Education Reforms in Africa: The University of Dar es Salaam Experience. Dar es Salaam, Tanzania: Dar es Salaam University Press.

Makulilo, V. (2012). Disconcerted Success of Students' Loans in Financing Higher Education in Tanzania. African Review, 41(2), 108-135.

Maxwell, J. A. (2013). Qualitative Research Design: An Interactive Approach (3rd ed.).

Nomura, S. (2011). Education Financing in sub Saharan Africa: Real Gains but Many Challenges in UNESCO-IUS. Financing Higher Education in Sub Saharan Africa: Meeting Challenges of Expansion. In Equity and Quality.

Rapley, T. (2007). Doing conversation, discourse and document analysis. London: Sage. http://dx.doi.org/10.4135/9781849208901

Sanyal, B. C. (2005). The Role of Higher Education in Obtaining EFA goals with Particular Focus on Developing Countries.

Savin-Baden, M., \& Major, C. H. (2010). New Approaches to Qualitative Research_ “Wisdom and Uncertainty”. Routledge, London. 
Schultz, T. W. (1981). Investing in People: The Economics of Population Quality. California and London: University of California Press, Ltd.

Sharan, M. B. et al. (2002). Qualitative Research in Practice. Jossey-Bass.

Sifuna, D. N., \& Sawamura, N. (2010). Challenges of Quality Education in Sub-Saharan African Countries. Nova Science Publishers, Inc., New York.

Stake, R. E. (2010). Qualitative Research. The Guildford Press.

TCU. (2009). Facts and Figures, Universites and University colleges. Tanzania Commission for Universities, Dar es Salaam.

UNESCO. (2010). Financing Education in sub Saharan Africa: Meeting the Challenges of Expansion, Equity and Quality. UIS, Dakar.

URT. (1995). Education and training policy. Dar es Salaam, Ministry of Education and Culture.

URT. (1998). Financial Sustainability of Higher Education in Tanzania. A report of the task force on Financial Sustainability of Higher Education in Tanzania. Dar es Salaam, Ministry of Science, Technology, and Higher Education.

URT. (1999). National Higher Education Policy. Dar es Salaam, Ministry of Science Technology and Higher Education.

URT. (2004). Cost sharing Policy Phase I. Ministry of Science Technology and Higher Education.

URT. (2004). Cost sharing Policy Phase II Ministry of Science Technology and Higher Education.

URT. (2004). Higher Education Students Loans Board (No. 9). Government Printing Press, Dar es Salaam.

URT. (2005). Review of Financial Sustainability in Financing Higher Education in Tanzania. Dar es Salaam, Ministry of Science, Technology, and Higher Education.

URT. (2005) United Republic of Tanzania Public Expenditure Review 1994/5-2004/05. Ministry of Finance, Dar es Salaam.

URT. (2007). Basic Statistics on Higher Education 2002/2003-2006/2007. Government Printing Press, Dar es Salaam.

Wiersma, W., \& Jurs, S. G. (2009). Research Methods in Education: An Introduction (9th ed.). Pearson, US.

World Bank. (2011). United Republic of Tanzania Public Expenditure Review 2010. Ministry of Finance and Development.

Yin, R. K. (1994). Case study research: Design and methods (2nd ed.). Thousand Oaks, CA: Sage.

\section{Copyrights}

Copyright for this article is retained by the author, with first publication rights granted to the journal.

This is an open-access article distributed under the terms and conditions of the Creative Commons Attribution license (http://creativecommons.org/licenses/by/3.0/). 